ROZ D Z I A E 1 .

\title{
EKONOMICZNE ASPEKTY PRAW WŁASNOŚCI. PERSPEKTYWA INSTYTUCJONALNA
}

\author{
Ewa Gruszewska ${ }^{1}$
}

\section{Wstęp}

Własność jest jedną z tych kategorii, bez których rozważania o gospodarce byłyby niekompletne. Trudno byłoby sobie wyobrazić, a jeszcze trudniej urzeczywistnić system instytucjonalny bez praw własności. Zasoby wykorzystywane w gospodarce są przedmiotem konfliktów, gdyż ich ilość jest nieadekwatna w stosunku do zapotrzebowania. Prawa własności jako jedna z podstawowych instytucji formalnych ogranicza skalę konfliktów. Wydaje się oczywiste, że system instytucjonalny pozbawiony tych praw byłby niekompletny i niesprawny oraz ograniczałby korzyści społeczeństwa. Gospodarka nie mogłaby wówczas sprawnie funkcjonować i rozwijać się.

Instytucje będące głównym obiektem zainteresowań ekonomii instytucjonalnej stanowią otoczenie procesów gospodarczych, zaliczane są do systemu regulacyjnego gospodarki. Można określać je jako różne normy i zasady, które oddziałują na postępowanie ludzi. Prawa własności to instytucja, której istnienie stanowi warunek rozwoju gospodarczego. Bez silnych i dobrze egzekwowanych praw proces tworzenia kapitału w różnych

\footnotetext{
${ }^{1}$ Dr hab. Ewa Gruszewska, prof. UwB, Uniwersytet w Białymstoku.
} 
postaciach byłby zaburzony i z pewnością nie osiągałby adekwatnej w stosunku do potrzeb dynamiki. Aktywność podmiotów w takich warunkach byłaby ograniczona jedynie do niewielkiego obszaru najlepiej znanego. Wyjście poza te ramy byłoby oceniane jako zbyt ryzykowne. Jednak taka działalność nie prowadziłaby do ekspansji na nowe rynki, zwiększenia dynamiki obrotów, inwestycji i innych.

W rozdziale podjęto rozważania dotyczące znaczenia praw własności w gospodarce. Przyjęto przy tym perspektywę instytucjonalną wskazując na zakorzenienie praw własności wśród innych instytucji.

\subsection{Istota praw własności}

Zagadnienie własności oraz praw do niej było przedmiotem rozważań już w starożytności. Regulacja własności początkowo była uproszczona i często dokonywana za pomocą rozwiązań nieformalnych (prawo zwyczajowe). Stopniowo jednak wykształcała się coraz większa różnorodność prawnych form użytkowania i osiągania korzyści z rzeczy, największą osiągnęła w warunkach gospodarki rynkowej ${ }^{2}$. Coraz większa liczba praw i zwyczajów w odniesieniu do własności stała się przyczyną dążeń do ujednolicenia podstaw prawnych własności ${ }^{3}$. Zagadnienie własności i praw należy wiązać z ziemią i nieruchomościami oraz z kapitałem, ponieważ dzięki nim powstaje wartość. „Formalny system własności to wodna elektrownia kapitału. To miejsce, w którym kapitał przychodzi na świat"4. Rozwój gospodarczy sprawił, że prawami własności obejmowano coraz więcej dóbr, początkowo tylko ludzi, następnie ziemię, a w kapitalizmie wszystkie czynniki wytwórcze. Obecnie istotne znaczenie mają też aktywa

${ }^{2}$ A. Sadowski, Własność a użytkowanie gruntów rolnych. Zarys tendencji rozwojowych, Wydawnictwo Uniwersytetu w Białymstoku, Białystok 2009, s. 65.

${ }^{3}$ A. Adamska, Własność i kontrola. Perspektywa akcjonariuszy spółek publicznych, Oficyna Wydawnicza SGH w Warszawie, Warszawa 2013, s. 20.

${ }^{4}$ H. J. de Soto, Tajemnica kapitału. Dlaczego kapitalizm triumfuje na Zachodzie a zawodzi gdzie indziej, Fijor Publ., Chicago-Warszawa 2002, s. 69. 
i wartości niematerialne, one również stają się przedmiotem uprawnień własnościowych.

W badaniach ekonomicznych we wcześniejszych okresach (w ekonomii klasycznej, czy też do XX wieku) tematyka praw własności nie była jednak podejmowana powszechnie. Również i instytucje, stanowiące reguły działania (formalne i nieformalne), traktowane były jako składowe otoczenia działalności gospodarczej, które z założenia, albo się nie zmieniało, albo uznawano, że nie wpływa na aktywność podmiotów. Kwestia praw własności odżyła na nowo w pracach instytucjonalistów. Ronald Coase na gruncie ekonomii neoklasycznej analizował zagadnienia praw własności jako podstawy systemu rynkowego. Analizował relację kosztów zewnętrznych oraz praw własności, wskazując przy tym na znaczenie kosztów transakcyjnych. Coase przyjmował istnienie praw własności za oczywiste ${ }^{5}$. Można stwierdzić, że ten noblista wprowadził do nauki kategorię praw własności jako odrębny przedmiot badań oraz wskazał drogę do zrozumienia ich roli w gospodarce. Umożliwiło to pogłębienie analiz praw własności w odniesieniu do różnych użytkowników - agentów. Badacz wskazał, że prawa własności mogą być definiowane, przechowywane, wymieniane i egzekwowane w odniesieniu do wielu atrybutów (zastosowań, funkcjonalności) zasobów gospodarczych ${ }^{6}$.

Wykorzystywaną obecnie w ekonomii instytucjonalnej koncepcję praw własności opracował Harold Demisetz ${ }^{7}$, który wskazał, że „prawa własności są instrumentem społeczeństwa, a ich znaczenie wynika z faktu, że pomagają ludziom kształtować oczekiwania, które są racjonalne i wynikają z interakcji z innymi. Oczekiwania te znajdują wyraz w prawie, zwyczajach i obyczajach społeczeństwa. Właściciel praw własności dysponuje zgodą pozostałych ludzi, aby działać w określony sposób. Może oczekiwać,

${ }^{5}$ H. Sato, The Emergence of "Modern" Ownership Rights Rather than Property Rights, "Journal of Economic Issues" 2018, t. LII, nr 3, s. 678.

${ }^{6}$ K. Foss, N. Foss, Coasian and modern property rights economics, "Journal of Institutional Economics" 2015, t. 11, nr 2, s. 392.

${ }^{7}$ A. Calbay, Property Rights and Theory of Value, MPRA Paper nr 25827, Munch 2006, s. 2; https://mpra.ub.uni-muenchen.de/id/eprint/25827 [data dostępu: 30.08.2019]. 
że pozostali członkowie społeczeństwa uniemożliwią innym ingerowanie w jego działania pod warunkiem, że nie są one zabronione"8. Badanie praw własności powinno obejmować wszystkie efekty korzystania z nich: przychody, koszty, czy też inne skutki bezpośrednie i pośrednie, które dotyczą jednostek-właścicieli (lub też innych podmiotów). Jednak to, w jaki sposób będzie alokowany zasób, nie wynika z samego prawa własności, ale zależy od potencjalnych korzyści, które można osiągnąć z jego zastosowania ${ }^{9}$. Rachunek ekonomiczny kieruje podmioty ku optymalnym wyborom.

Niepodważalne dzisiaj jest to, że bazą każdego porządku ekonomicznego i prawnego jest instytucja własności. Odpowiednio sformułowane przepisy oraz ich egzekwowanie są niezbędne do działania sprawnego systemu ekwiwalentnych wymian, konkurencji, a zatem i każdej współczesnej gospodarki. Liberałowie uważali, że własność prywatna stanowi zabezpieczenie prawa do wolności wszystkich ludzi. Wszelkie formy ograniczania własności prywatnej w efekcie działania państwa, czy też monopoli należy utożsamiać z zamachem na wolność jednostki oraz negatywnie wpływają na rozwój i postęp ${ }^{10}$. „Gospodarka rynkowa wymaga przede wszystkim

${ }^{8}$ H. Demstetz, Toward a Theory of Property Rights, „American Economic Review” 1967 , t. 57 , nr 2, s. 347.

9 „To, czy nowo odkryta jaskinia należy do człowieka, który ją odkrył, czy do człowieka, na którego ziemi znajduje się wejście do jaskini, czy do człowieka, którego własnością jest powierzchnia nad jaskinią, bez wątpienia zależy od prawa własności. Lecz prawo to jedynie określa osobę, z którą trzeba zawrzeć umowę, żeby móc korzystać z jaskini. Czy ta jaskinia będzie używana do przechowywania archiwów bankowych, czy jako zbiornik gazu ziemnego, czy do hodowli pieczarek, nie zależy od prawa własności, lecz od tego, czy bank, firma gazowa lub pieczarkarnia zapłaci najwięcej, aby móc ją wykorzystywać"; R.H. Coase, The Federal Communications Commission, "The Journal of Law and Economics" 1959, October, s. 25 [za:] R.H. Coase, Uwagi na temat problemu kosztu społecznego, [w:] R.H. Coase, Firma, rynek i prawo, Oficyna Wolters Kluwer business, Warszawa 2013, s. 143.

${ }^{10}$ U. Zagóra-Jonszta, Własność w ujęciu wybranych kierunków myśli ekonomicznej, [w:] Własność i kontrola $w$ teorii i praktyce, B. Polszakiewicz, J. Boehlke (red.), cz. 1, Wydawnictwo UMK, Toruń 2007, s. 51. 
uporządkowania praw własności przez precyzyjne zdefiniowanie tytułów własności i przypisanie ich konkretnym osobom"11.

Prawo własności określić można jako egzekwowalne uprawnienie do podejmowania aktywności przez jednostki w określonym zakresie. Chodzi o takie działania, które osoby fizyczne mogą przedsięwziąć wobec innych osób w odniesieniu do jakiejś rzeczy (która jest przedmiotem własności). W sytuacji, gdy jedna osoba ma prawo własności danego zasobu, pozostałe mają współmierny obowiązek przestrzegania tego prawa ${ }^{12}$. Generalnie wyjaśnienie istoty praw własności wymaga spojrzenia od strony prawnej i odszukania odpowiednich ustanowionych przepisów, które je precyzują. W literaturze można jednak odnaleźć dużo szersze postrzeganie tej kategorii, obejmujące również prawo zwyczajowe - czyli instytucje nieformalne ${ }^{13}$. Choć włączenie tych ostatnich do wspólnej wiązki uprawnień własnościowych wydaje się zbyt szerokie, to jednak zwraca uwagę na kwestie kulturowe i szersze środowisko instytucjonalne (np. autorytety moralne) w kształtowaniu motywów prowadzenia działalności gospodarczej. Geoffrey M. Hodgson wskazuje, że motywacje umożliwiają objaśnianie egzekwowania praw własności we współczesnej gospodarce ${ }^{14}$. Wydaje się też, że mogą wpływać na ewolucję samych praw. Noblista wszedł w dyskusję z naukowcami liberalnymi, np. z Friedrichem von Hayekiem, którzy redukowali prawo własności jedynie do zwyczaju. Wskazywał argumenty, z powodu których prawo stanowione, stało się ważniejsze od zwyczajowego ${ }^{15}$ :

- prawo pojawiło się wraz z upływem czasu, w obliczu naruszania obyczajów; konflikty wymagały rozwiązań coraz bardziej formalnych (np. przez władcę);

${ }^{11}$ A. Sadowski, dz. cyt., s. 49.

${ }^{12}$ E. Ostrom, How Types of Goods and Property Rights Jointly Affect Collective Action, "Journal of Theoretical Politics" 2003, t. 15, nr 3, s. 249.

${ }^{13}$ G.D. Libecap, Contracting for Property Rights, Cambridge University Press, Cambridge, New York 1989, s. 1.

${ }^{14}$ G.M. Hodgson, Much of the 'economics of property rights' devalues property and legal rights, "Journal of Institutional Economics" 2015, t. 11, nr 4, s. 686.

${ }^{15}$ Tamże. 
- egzekwowanie przepisów prawnych opiera się na swoistych umowach, porozumieniach czy zwyczajach w stosunkowo niewielkich wspólnotach; w dużych zbiorowościach rozwiązania nieformalne mogą być niewystarczające;

- coraz większa złożoność stosunków społecznych oraz rozprzestrzenianie się ludności zwiększały wagę przepisów ustanawianych przez władcę i moralne autorytety, a zmniejszały znaczenie zwyczajów czy tradycji.

Prawa własności są to relacje powstające między ludźmi na tle posiadania i użytkowania zasobów. Ich istotą jest podjęcie określonych działań wobec dóbr. W aspekcie prawnym można mówić o trzech uprawnieniach: posiadaniu, korzystaniu i dysponowaniu ${ }^{16}$. Prawa własności są silnie związane z podstawowym problemem ekonomicznym - rzadkością zasobów oraz alternatywnymi ich zastosowaniami. Gdyby wszystkie dobra zaspokajające ludzkie potrzeby były wolne, własność nie byłaby potrzebna, gdyż wykorzystanie danej rzeczy przez jednostkę nie stałoby w sprzeczności z użytkowaniem jej przez kogokolwiek innego. Jednak, gdy konsumenci czy producenci konkurują o zasoby powstaje konieczność uporządkowania relacji między ludźmi w odniesieniu do tych zasobów ${ }^{17}$. Konflikty na tle dostępu do dóbr zmniejszają korzyści z użytkowania zasobów. W obliczu konfliktów i konkurowania o zasoby ludzie dążą do wypracowania wzorców postępowania. Zastosowanie tych schematów zmniejsza potencjalne straty z nieoptymalnej alokacji zasobów i prowadzi do zwiększenia korzyści jednostek i grup. Budowa instytucji porządkujących stosunek ludzi do zasobów ogranicza skalę konfliktów o dostęp i korzyści z użytkowania dóbr. Prawa własności są zatem instytucjami i jako takie kształtują

${ }^{16}$ M. Pietrzak, Własność wspólna w kapitalizmie, [w:] Zrozumieć kapitalizm. Podejście ewolucyjno-instytucjonalne, A. Ząbkowicz, M. Miszewski, P. Chmielnicki, S. Czech (red.), Oficyna Wydawnicza „Humanitas”, FMI, Sosnowiec 2018, s. 110.

${ }^{17}$ D. Juruś, Dzieje własności prywatnej. Od starożytności do wspótczesności, FijoRR Publishing, Warszawa 2016, s. 282. 
wzorce postępowania ludzi w związku z własnością, obejmują także sankcje z tytułu nieprzestrzegania tych praw ${ }^{18}$. Uprawnienia te zabezpieczają możliwość korzystania z określonego dobra przez jego właściciela ${ }^{19}$ oraz w określonych przypadkach również przez inne osoby. W zasadzie prawa własności to szereg powiązanych uprawnień właściciela/posiadacza i innych osób, którym może być przekazanych część tych praw. Można wśród nich wymienićé

- prawo do posiadania;

- prawo do użytkowania;

- prawo do zarządzania (np. dokonywania transferu praw);

- prawo do dochodu z zasobu;

- prawo do tworzenia kapitału (z danego aktywa);

- prawo do bezpieczeństwa (np. przed utratą własności);

- prawa transmisyjności (ciągłość uprawnień w czasie);

- prawo do zwrotu własności po zniesieniu obciążenia jej np. długiem;

- zakaz użytkowania dobra na szkodę innych osób;

- obowiązek wydania zasobu w celu spłaty zobowiązań.

Powyższe zestawienie jest powszechnie uznawane przez naukowców zajmujących się prawami własności i stanowi punkt wyjścia do analiz składowych tych praw ${ }^{21}$. Elinor Ostrom wskazywała na pięć głównych praw znajdujących się w wiązce uprawnień związanych z własnością, przy czym sam właściciel może korzystać z nich w pełni. Są to następujące prawa ${ }^{22}$ :

${ }^{18}$ S. Pejovich, The Economics of Property Rights: Towards a Theory of Comparative Systems, Kluwer AP, Dordrecht, Boston, London 1990, s. 27.

${ }^{19}$ D. Lueck, T.J. Micelli, Property law, [w:] Handbook of Law and Economics, M.A. Polinsky, S. Shavell (red.), t. 1, Elsevier, North-Holland 2007, s. 186.

${ }^{20}$ A.M. Honoré, Ownership, [w:] Oxford Essays in Jurisprudence, A.G. Guest (red.), Oxford University Press, Oxford 1961, s. 113; reprinted in the "Journal of Institutional Economics" 2013, t. 9, nr 2.

${ }^{21}$ A. Adamska, dz. cyt., s. 28.

${ }^{22}$ E. Ostrom, dz. cyt. 
- nieograniczony dostęp do zasobu oraz korzystania z nich np. prawo do przebywania na danej działce (dostęp);

- korzystanie z produktów z zagospodarowania danego zasobu np. zbieranie plonów i tym samym czerpania dochodów (wykorzystanie);

- możliwość wyboru sposobu wykorzystania własności oraz jego zmiany (zarządzanie);

- możliwość wskazania osób, które mogą również korzystać z danej własności (i na jakich zasadach) oraz możliwość wykluczania osób z korzystania z dobra;

- zbycie własności bądź prawa zarządzania czy korzystania z niej (alienacja).

Poszczególne rodzaje praw własności mogą przynależeć również do innych osób niż tylko do właścicieli. Pozycja danej osoby wobec pełnego posiadacza zasobu jest kluczowa w dookreśleniu i możliwości korzystania z praw jej przypisanych (tabela 1.1.).

Tabela 1.1. Prawa własności wynikające z pozycji zajmowanej wobec zasobu

\begin{tabular}{lccccc}
\hline & $\begin{array}{c}\text { Pełny } \\
\text { posiadacz }\end{array}$ & Właściciel & $\begin{array}{c}\text { Upoważniony } \\
\text { petent } \\
\text { authorized } \\
\text { claimant) }\end{array}$ & $\begin{array}{c}\text { Upoważniony } \\
\text { użytkownik } \\
\text { (authorized } \\
\text { user) }\end{array}$ & $\begin{array}{c}\text { Upoważniony } \\
\text { uczestnik } \\
\text { (authorized } \\
\text { entrant) }\end{array}$ \\
\hline \hline Dostęp & $\times$ & $\times$ & $\times$ & $\times$ & $\times$ \\
\hline Wykorzystanie & $\times$ & $\times$ & $\times$ & $\times$ & \\
\hline Zarządzanie & $\times$ & $\times$ & $\times$ & & \\
\hline Wykluczanie & $\times$ & $\times$ & & & \\
\hline Alienacja & $\times$ & & & & \\
\hline
\end{tabular}

Źródło: E. Ostrom, How Types of Goods and Property Rights Jointly Affect Collective Action, "Journal of Theoretical Politics" 2003, t. 15, nr 3, s. 251.

Własność powszechnie utożsamia się z posiadaniem, czyli możliwością kontroli zasobów i zarządzania nimi. Brak rozróżnienia między nimi 
stanowił przyczynę trudności w definiowaniu oraz w zastosowaniu analizy praw własności w badaniach instytucjonalnych ${ }^{23}$. Podstawą prawa własności do zasobu jest uznanie tego prawa przez inne jednostki, poprzez mechanizmy instytucjonalnej akredytacji i legitymacji. Prawo własności to relacja ekonomiczna nie tylko oznaczająca stosunek człowieka do rzeczy, ale też do innych osób. Obejmuje prawa, możliwości, ograniczenia, korzyści, czy też obowiązki. Przekazanie/sprzedaż prawa własności innej osobie wymaga uczestnictwa w tym akcie jeszcze przynajmniej jednej strony - państwa ${ }^{24}$.

\subsection{Prawa własności wśród instytucji}

Prawa własności jako normę stanowioną należy rozpatrywać łącznie z innymi instytucjami, ponieważ żadna reguła czy norma nie działa samodzielnie. Mówią o tym też sami prawnicy wskazując powiązania między różnymi przepisami. „Pojedyncze rozwiązania łączą się w bardziej złożone opisy całych sekwencji działań, podejmowanych w celu osiągnięcia jakiejś korzyści wymiernej lub niewymiernej (zaspokojenia przez to jakiejś potrzeby). (...) Gotowe schematy działania (komplety normatywne), upowszechniane w społeczeństwie i utrwalane za pomocą procesów formalizacyjnych, zwalniają z konieczności samodzielnego opracowywania sposobów działania na użytek każdej sytuacji z osobna"25.

${ }^{23}$ G.M. Hodgson podważał twierdzenie, że rozróżnienie między własnością a posiadaniem nie musi być dokonane, aby prowadzić analizę ekonomiczną, gdyż zachowania mogłyby być wyjaśnione czy przewidziane na podstawie faktycznego posiadania. G.M. Hodgson, dz. cyt., s. 686.

${ }^{24}$ Tenże, The Economics of Property Rights' is about neither Property nor Rights, 31 August 2014, s. 5; http://econweb.umd.edu/ davis/eventpapers/HodgsonRights.pdf [data dostępu: 02.09.2019].

${ }^{25}$ P. Chmielnicki, J. Paśnik, Rozpoznanie treści instytucji jako warunek sine qua non oceny ich skutków, [w:] Zrozumieć kapitalizm..., s. 156-157. 
Instytucje stały się przedmiotem coraz większego zainteresowania naukowców w latach 70. i 80. XX wieku. „W nurcie nowej ekonomii instytucjonalnej (NEI) w porównaniu do tzw. starej ekonomii instytucjonalnej, prowadzone są nie tylko badania opisowe dotyczące roli instytucji w gospodarce, ale też opracowuje się i stosuje narzędzia analizy ekonomicznej umożliwiające zastosowanie badań empirycznych" ${ }^{26}$. Spojrzenie na gospodarkę z perspektywy instytucjonalnej wymagało odejścia od tradycyjnego ujęcia gospodarki w ekonomii, od tzw. głównego nurtu. Wydaje się to oczywiste w świetle zmian w procesach produkcji, pojawiania się coraz to nowych zjawisk, w tym „nowej” gospodarki ${ }^{27}$. W klasycznych czy neoklasycznych analizach przedmiotem badań była realna gospodarka postrzegana zwykle w wymiarze fizycznym i względnie dobrze mierzalnym. Modele wzrostu gospodarczego opisujące procesy wzrostu produkcji i dochodów, inwestycji, wskazujące fundamentalne czynniki dynamiki gospodarczej: kapitał, pracę czy postęp techniczny okazały się niewystarczające w wyjaśnieniu przyczyn niedorozwoju gospodarczego. W badaniach ekonomistów sięgnięto po głębiej zakorzenione źródła wzrostu. Jeden z nurtów poszukiwań to właśnie ekonomia instytucjonalna.

Instytucje kształtują się w efekcie społecznych interakcji podczas różnorakich transakcji. Instytucje to również otoczenie, które wpływa na powstawanie norm działania, to ograniczenia formalne i nieformalne ${ }^{28}$. Niestandardowe wybory dokonywane przez jednostki nie mają dużego wpływu na instytucje. Jednak powtarzające się działania, masowość zjawisk mogą przekroczyć tzw. masę krytyczną i wówczas zmienia się układ

\footnotetext{
${ }^{26}$ Ł. Hardt, Optymalność instytucji w perspektywie implementacji zasad dobrego rządzenia, [w:] Jakość rządzenia w Polsce. Jak ją badać, monitorować i poprawiać?, J. Wilkin (red.), Wydawnictwo Naukowe Scholar, Warszawa 2013, s. 57.

${ }^{27}$ Szerzej: A. Wojtyna, Czy tradycyjna ekonomia pozwala zrozumieć tzw. nowa gospodarkę?, [w:] Czy ekonomia nadąża z wyjaśnieniem rzeczywistości?, A. Wojtyna (red.), t. 1, Bellona-PTE, Warszawa 2001, s. 167-189.

${ }^{28} \mathrm{~J}$. Wilkin, Instytucjonalne i kulturowe podstawy gospodarowania. Humanistyczna perspektywa ekonomii, Wydawnictwo Naukowe Scholar, Warszawa 2016, s. 147.
} 
sił społecznych i ekonomicznych. Tworzą się wówczas nowe wzorce działania - czyli instytucje ${ }^{29}$. Mogą być one ustanowione i narzucone społeczeństwu jak instytucje formalne (w tym normy prawne), lub też być elementem kultury społecznej, tak jak zwyczaje, normy społeczne - instytucje nieformalne.

Instytucje są powszechne. Nie ma działania, które nie byłoby regulowane przez instytucje, przez systemy prawne czy normy społeczne. Wynika to z tego, że stanowią one swoistą sieć zależności wiążącą wszystkie jednostki w społeczeństwie. „Instytucje są w głowach ludzi. Jeśli konkretna instytucja nie zakorzeni się w umyśle człowieka i nie zacznie wpływać na jego zachowanie, to nie jest instytucją w sensie społecznym. Normy prawne, które nie spełniają takiej regulującej funkcji w życiu człowieka, czy organizacje biznesowe lub państwowe, które nie wpływają w sposób regularny i trwały na zachowania ludzi, są martwe jako instytucje społeczne"30. Instytucje umożliwiają realizację celów poszczególnych jednostek i zbiorowości, a także wpływają na przewidywanie wyników działań.

Powstanie czy zmiana instytucji stanowią fakty instytucjonalne. Mogą one zaistnieć tylko w warunkach zbiorowej akceptacji ${ }^{31}$. W tym kontekście własność i jej prawna ochrona pojawiły się w wyniku ewolucyjnych zmian norm społecznych, zwyczajów, tradycyjnych wzorców działania. Instytucja ta powstała, by zwiększać korzyści społeczne. Dzięki prawom własności ograniczeniu ulega niepewność działań gospodarczych, następuje większa stabilizacja interakcji międzyludzkich, zwiększa się motywacja do akumulowania i inwestowania w społeczeństwie ${ }^{32}$.

${ }^{29}$ M. Owczarczuk, Zmiany instytucjonalne $w$ gospodarce - wybrane aspekty teoretyczne, „Optimum. Studia Ekonomiczne” 2013, nr 2 (62), s. 37.

30 J. Wilkin, dz.cyt., s. 98-99.

${ }^{31}$ G.H. Cole., Economic Property Rights" as "Nonsense upon Stilts": A Comment on Hodgson, "Journal of Institutional Economics" 2015, t. 11, nr 4, s. 726.

32 A. Adamska, dz. cyt., s. 31. 
Rysunek 1.1. Poziomy systemu instytucjonalnego

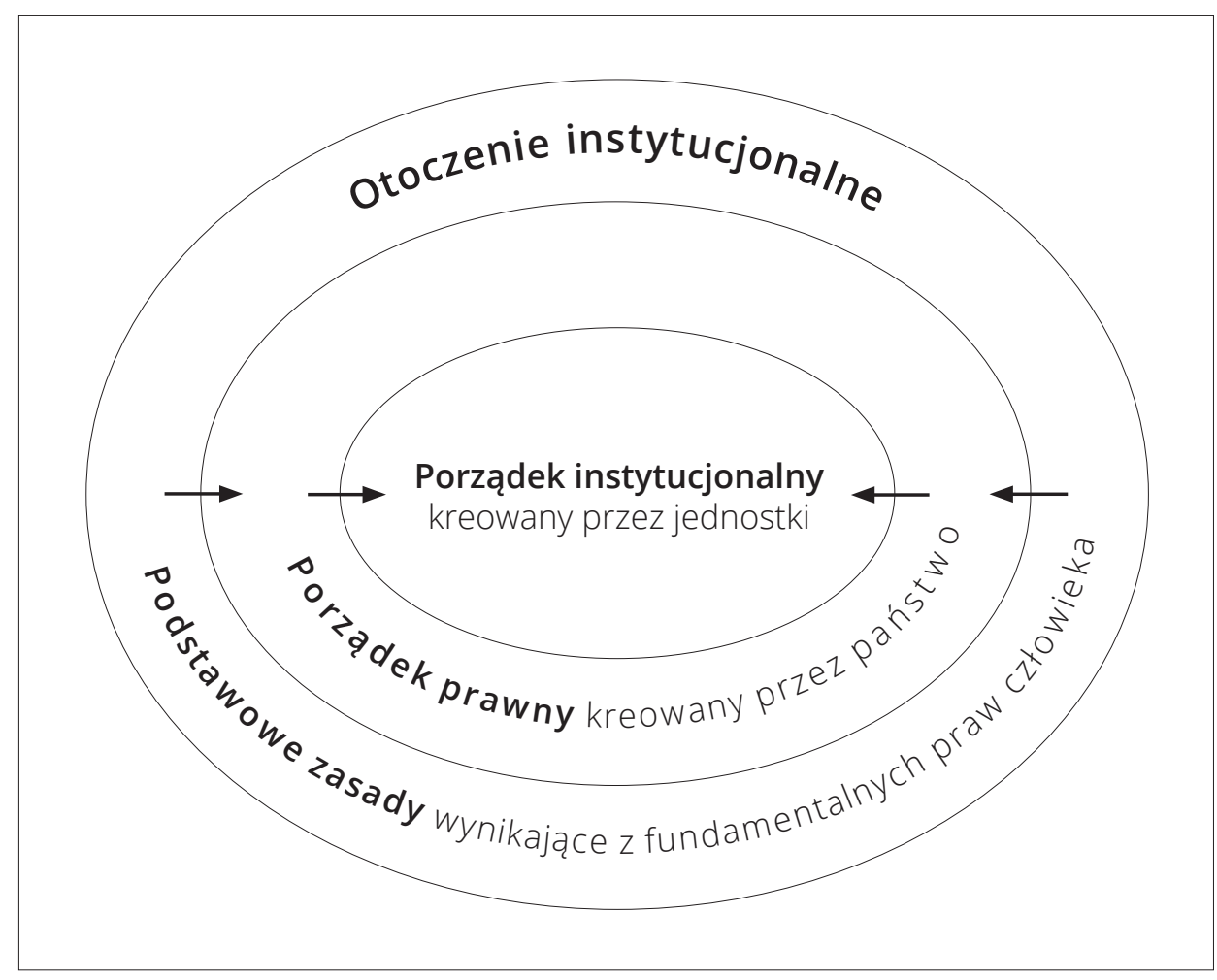

Źródło: S. Borner, F. Bodmer, M. Kobler, Institutional Efficiency and its Determinants. The Role of Political Factors in Economic Growth, Development Centre Studies OECD, Paris 2004, s. 30.

Układ instytucjonalny jest wielopoziomową i w sposób zróżnicowany powiązaną strukturą reguł (rysunek 1.1.). Dodatkowo ciągle ewoluuje. Instytucje dopasowują się do siebie, mogą być względem siebie komplementarne bądź substytucyjne, jedne reguły mogą wypierać inne. Mimo to należy traktować je nie tylko jako zbiór różnych elementów, ale jako kompleksowy układ, który jest źródłem bodźców: stymulant i destymulant w działaniu jednostek i grup. Instytucje zawsze pozostają w silniejszych bądź słabszych zależnościach. Są elementami większej całości - mechanizmu regulacyjnego, który wieloaspektowo oddziałuje na sferę realną. Nie przeczy to też przypadkom, kiedy różne instytucje mogą pozostawać 
w konflikcie, a ich działanie może generować zupełnie przeciwstawne bodźce. Dotyczy to również praw własności.

„System połączenia wiązek praw własności powoduje istnienie zróżnicowanych systemów tych praw jako podstawy różnych systemów instytucjonalnych"33. System prawny, w tym odnoszący się do własności, jest w naturalny sposób powiązany z innymi instytucjami. Działanie każdej normy prawnej należy rozpatrywać w kontekście innych obowiązujących zapisów prawa ${ }^{34}$, a także nieformalnych norm, zwyczajów i innych. W danym momencie działają jednocześnie wszystkie instytucje, choć można sobie tego wcale nie uzmysławiać.

Sprawnie działający system praw własności czy szerzej instytucji formalnych nie może być skuteczny bez wsparcia instytucji nieformalnych. Instytucje nieformalne są źródłem stanowienia prawa, ale też wzmocnienia działania przepisów. Pierwotnie wypracowane zwyczaje w postępowaniu przyjmują coraz bardziej sformalizowaną postać. Prawo może być również „przeszczepione” z innych krajów. Jednak wówczas może pojawić się niezgodność z wzorcami kulturowymi w danym społeczeństwie. Skutkiem tego będzie traktowanie instytucji importowanych jako obcych i mogą być one odrzucane jako sprzeczne z istniejącym porządkiem. W warunkach ostrej sprzeczności między normami formalnymi i nieformalnymi, te drugie mogą stać się środkiem realizacji interesów grup społecznych ${ }^{35}$.

33 Z. Staniek, Ekonomia instytucjonalna. Dlaczego instytucje są ważne, Difin, Warszawa 2017, s. 38.

34 „[W]spółzależność pomiędzy poszczególnymi rozwiązaniami instytucjonalnymi, zachodząca w ramach tego samego kompletu normatywnego, może mieć istotny wpływ na rozumienie treści poszczególnych rozwiązań! Innymi słowy, modyfikują one swoje znaczenie „lokalnie”, tzn. w zależności od roli, jaką pełni dane rozwiązanie w określonym komplecie normatywnym"; P. Chmielnicki, J. Paśnik, dz. cyt., s. 159.

${ }^{35}$ E. Gruszewska, Transformacja instytucji nieformalnych $w$ Polsce, „Gospodarka Narodowa" 2012, nr 3, s. 67. 


\subsection{Rola praw własności w gospodarce}

Sprawna i dynamiczna gospodarka wymaga dobrze ustanowionych i egzekwowanych praw własności. Inwestorzy nie będą zainteresowani lokowaniem kapitału, jeśli ryzyko instytucjonalne będzie przez nich oceniane jako wysokie. Dochodzenie swoich praw w warunkach słabego prawa jest bardzo trudne i nie gwarantuje pozytywnego dla inwestora rozstrzygnięcia sporu. Jeśli prawo jest silne i jest powszechnie przestrzegane ${ }^{36}$ nie stanowi źródła dodatkowego ryzyka w procesie inwestowania i lokalizacji firmy na danym obszarze administracyjnym. Wysoka jakość praw własności jest gwarancją wolności gospodarczej i dynamiki podmiotów. Ważne jest także stworzenie sprawnego systemu wymiaru sprawiedliwości. „Własność prywatna ożywia system [rynkowy], czyniąc ludzi odpowiedzialnymi i doprowadzając do zamienności zasobów, rejestrując transakcje i zapewniając wszystkie warunki niezbędne do tego, by dobrze działał system monetarny i bankowy oraz właściwie funkcjonowały inwestycje. Połączenie kapitału i współczesnego pieniądza dokonuje się poprzez własność"37.

Zakłada się, że w ramach funkcjonujących norm prawnych jednostki działają racjonalnie oraz kierują się maksymalizacją użyteczności. „Baczniejszą uwagę będziemy przykładali do dóbr, które są naszą własnością, mniej będziemy chronili dobra, które dzierżawimy. Im uprawnienia własnościowe, przypisane do konkretnych dóbr są pełniejsze, tym efektywność gospodarki większa, gdyż zasoby w sposób nieskrępowany mogą być transferowane do miejsc, gdzie ich efektywność będzie najwyższa”38. Bez „dobrych” praw

${ }^{36}$ Gdy działanie instytucji formalnych jest wspierane przez odpowiadające im instytucje nieformalne, zrównoważony system instytucjonalny staje się bezpieczną areną dla podejmowania działań gospodarczych. Normy społeczne wzmacniają skuteczność przepisów prawnych, sprzyjają przestrzeganiu prawa oraz obniżają koszty transakcyjne, co w oczywisty sposób prowadzi do zwiększenia aktywności gospodarczej; Z. Staniek, dz. cyt., s. 91-94.

${ }^{37}$ H. J. de Soto, dz. cyt., s. 86.

${ }^{38}$ A. Sadowski, Nowa ekonomia instytucjonalna jako próba poszerzenia możliwości analitycznych ekonomii neoklasycznej w stosunku do własności użytkowania ziemi, „Rocznik Stowarzyszenia Naukowców Polaków Litwy” 2008/2009, t. 7-8, s. 117. 
własności nie może mieć miejsca efektywna alokacja wszystkich zasobów gospodarczych: materialnych, naturalnych, ludzkich czy też intelektualnych. Zasoby, w odniesieniu do których prawo własności jest nieustalone lub niejasne, nie mogą stać się przedmiotem transakcji. Gdy nie można dociec, kto ma do nich prawo, nie mogą być użyte jako źródło kreowania kapitału i zwiększania dochodów. Nie mogą stać się bazą dla powiększania aktywów czy też być użyte jako zabezpieczenie kredytu ${ }^{39}$. Brak dookreślenia praw własności, luki w prawie czy też niesprawność w ich egzekwowaniu włącza oportunizm jednostek i grup. Instytucje są bowiem silnie związane z interesami jednostek i grup, gdyż umożliwiają ich realizację. Należy zwrócić uwagę, że instytucje działają w kierunku zwiększenia korzyści społecznych, stąd mogą ograniczać zachowania nakierowane tylko na korzyści własne ${ }^{40}$. „Co więcej, są narzędziem społecznie uprawnionym, którego formalna i/lub nieformalna legitymizacja nadaje instytucjom atrybut trwałości i stabilności”41.

Słabo lub nieokreślone prawa własności uniemożliwiają ich egzekwowanie. Szereg procesów zachodzących w gospodarce od początku XX wieku doprowadziło do pogłębiania się niekompletności i niewyłączności praw własności. „Niekompletność oznacza formalny bądź nieformalny zanik części cząstkowych praw własności, tj. braku możliwości podjęcia decyzji co do konkretnego sposobu (np. prawo do sprzedaży, wynajmu, darowizny, zniszczenia czy zaniechania użytkowania) rozporządzania ograniczonymi zasobami. Niewyłączność natomiast oznacza, że jest niemożliwe lub znacznie ograniczone wykluczenie kogokolwiek (decydenta nieumocowanego na prawach własności) z rozporządzania i/lub korzystania z danego dobra" ${ }^{\$ 2}$.

\footnotetext{
${ }^{39}$ H. J. de Soto, dz. cyt., s. 26.

${ }^{40}$ A. Ząbkowicz, Jak rozumiany jest interes $w$ ekonomii, „Studia i Prace Wydziału Nauk Ekonomicznych i Zarządzania Uniwersytetu Szczecińskiego" 2016, nr 44/2, s. 404.

41 A. Kondratowicz, Wolność gospodarcza. Pomiar, percepcja, zmiany instytucjonalne, Towarzystwo Ekonomistów Polskich, Warszawa 2013, s. 186.

${ }^{42}$ W. Misiński, Instytucjonalna teoria przedsiębiorstwa, [w:] Nowa ekonomia instytucjonalna a nauki o zarządzaniu, „Prace Naukowe Wyższej Szkoły Bankowej w Gdańsku” 2016, t. 48, s. 246.
} 
Nie działa mechanizm wykluczania innych jednostek czy grup z zawłaszczania zasobów oraz czerpania korzyści z ich użytkowania. Dysponenci określonych aktywów nie mogą osiągać oczekiwanych dochodów i ograniczyć strumienia korzyści płynącego do innych nie-właścicieli. Trudno jest także sankcjonować działania tych osób, które w przebiegły sposób dążą do realizacji swoich celów. Oportunizm ujawnia się w przypadkach niekompletnego lub zniekształconego ujawnienia informacji, co staje się podstawą świadomie podejmowanych wysiłków skierowanych na wprowadzenie innych w błąd. Jego efektem jest zatajanie czy zagmatwanie sprawy w taki sposób, aby utrudnić działanie prawowitego posiadacza. Działania oportunistyczne kreują asymetrię informacji, co komplikuje aktywność podmiotów gospodarczych. Gdyby nie ujawniał się oportunizm, wszystkie aktywności mogłyby być regulowane przez zasady, normy, reguły ${ }^{43}$. Zmniejsza to sprawność ekonomiczną, powiększa koszty transakcyjne, ogranicza zaufanie do stron transakcji, negatywnie wpływa na internalizację efektów zewnętrznych. Ludzie dążą, by osiągnąć większe korzyści dla siebie i nikt nie może ponieść odpowiedzialności za ten transfer. Działania te ograniczają korzyści społeczeństwa, obecne i przyszłe. Oczywistym przykładem jest masowy wyrąb Puszczy Amazońskiej. Niewyjaśniony charakter prawny dużych obszarów stał się przyczyną nielegalnego użytkowania dla własnych celów (wylesianie, przekształcanie gruntów w pastwiska i pola uprawne) oraz spekulacji gruntami. Organisation for Economic Cooperation and Development (OECD) podaje, że do 2010 roku około 2/3 oczyszczonych gruntów zostało przekształconych w pastwiska ${ }^{44}$. W 2011 roku jedynie 4\% obszaru Amazonii (lub 13\% niepublicznych obszarów gruntów) posiadało ważny tytuł własności ${ }^{45}$ (rysunek 1.2.). W porównaniu do

43 O. Williamson, Ekonomiczne instytucje kapitalizmu. Firmy, rynki, relacje kontraktowe, Wydawnictwo Naukowe PWN, Warszawa 1998, s. 60-61.

${ }^{44}$ Fifth National Report to the Convention on Biological Diversity Brazil, Ministry of the Environment, Brasília, 2015, s. 22-23; www.cbd.int/doc/world/br/br-nr05-en.pdf [data dostępu: 10.07.2019].

45 OECD Environmental Performance Reviews Brazil 2015, OECD Publishing, Paris 2015, s. 190 . 
tego „na Zachodzie (...) każda parcela, każdy budynek, każdy ważniejszy element wyposażenia reprezentowany jest przez dokument własności, będący widomym znakiem wszechobecnego, ukrytego procesu, który łączy wszystkie zasoby z resztą gospodarki. Dzięki temu »procesowi reprezentacji«majątek może, obok swej egzystencji materialnej, wieść niewidoczny, równoległy żywot”"46 i stać się źródłem kapitału.

Rysunek 1.2. Prawa własności w Amazonii, początek XXI wieku

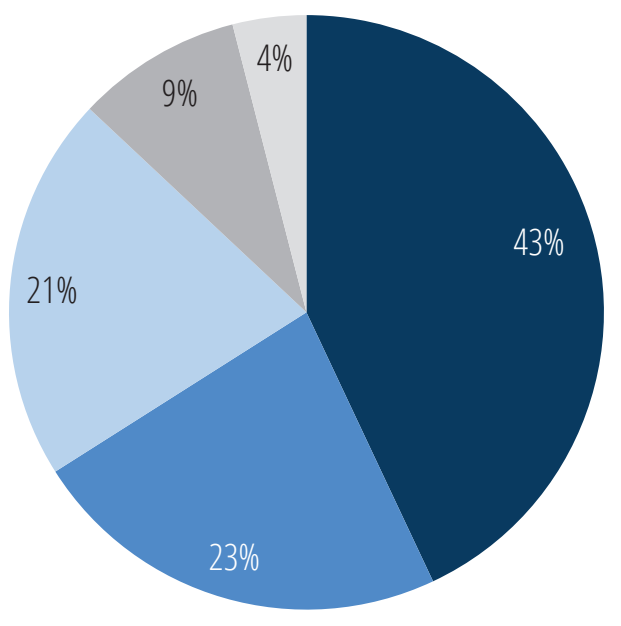

- Obszary chronione i ziemie autochtoniczne

Prawdopodobnie własność prywatna niepotwierdzona przez INCRA*

- Prawdopodobnie własność publiczna poza obszarami chronionymi

Tereny okupowane

Prywatna własność zarejestrowana przez INCRA

* INCRA: National Institute for Colonization and Agrarian Reform.

Źródło: B. Brito, P. Barreto, Os riscos e os princípios para a regularização fundiária na Amazônia, „Imazon” 2009, nr 10, [za:] OECD Environmental Performance Reviews Brazil 2015, OECD Publishing, Paris 2015, s. 191.

Gdy zasoby nie są chronione i każdy bez kłopotu może uzyskać do nich dostęp, dążenia jednostek do osiągnięcia bieżących korzyści własnych

${ }^{46}$ H. J. de Soto, dz. cyt., s. 26. 
uniemożliwiają akumulację i reprodukcję kapitału. Brak uprawnień własnościowych do wykluczania (kto może korzystać, a kto nie) oraz zarządzania (komu własność ma służyć i w jaki sposób) staje się barierą rozwoju gospodarczego. Brak ochrony zasobów, w efekcie braku prywatnych praw własności wymaga ponoszenia wysokich kosztów kontroli przez państwo (o ile dostrzeże konieczność ograniczenia strat społecznych w długim okresie) lub samego właściciela. Uprawnienia decyzyjne powinny zostać przekazane do wybranych zarządzających lub instytucji, w tym centralnych ${ }^{47}$, a własność powinna być chroniona przez państwo. Proces zmiany obowiązujących praw może być trudny: ludzie mogą unikać współpracy i przedstawiać sprzeczne w stosunku do innych osób stanowiska (roszczenia prywatne). Politycy i biurokraci uczestniczący w tworzeniu nowych praw będą starali się uwzględniać korzyści własne, a nie społeczne. Polityczny proces stanowienia prawa własności może prowadzić do podziałów ze względu na efekty dystrybucyjne przydziału własności ${ }^{48}$.

Zbigniew Staniek wskazywał szereg funkcji, które pełnią prawa własności w przestrzeni gospodarczej. Zaliczyć do nich można funkcje: „bodźcowo-motywacyjną (zachowania właścicielskie), rekompensaty za niepełne czy niekompletne kontrakty, wpływu na koszty transakcyjne (sprzężenia zwrotne praw własności i tych kosztów), dochodowo-majątkową (korzyści z własności), warunkującą rozwój rynku kapitałowego (obrót akcjami to wymiana praw własności), ograniczającą nadmierne regulacje państwowe (np. konstytucyjna ochrona praw własności), zwiększającą efektywność alokacyjną zasobów (znaczenie rozkładu praw w sytuacji wysokich kosztów transakcyjnych) czy odzwierciedlającą strukturę interesów ekonomicznych i siły grup interesu" ${ }^{49}$. Szczególnie istotne

\footnotetext{
47 T.L. Anderson, L.F. Huggins, The Property Rights Path to Sustainable Development, The Legacy of Milton and Rose Friedman's Free to Choose Economic Liberalism at the Turn of the 21st Century, October 23-24, 2003, A Conference Hosted by the Federal Reserve Bank of Dallas, s. 67; http://www.dallasfed.org/research/ pubs/ftc/anderson_huggins.pdf [data dostępu: 30.08.2019].

${ }^{48}$ G.D. Libecap, dz. cyt., s. 4.

49 Z. Staniek, dz. cyt., s. 116.
} 
wydają się być sprzężenia, jakie powstają na linii: prawa własności - dynamika gospodarcza, gdyż ostatecznym efektem działania instytucji jest wzrost aktywności jednostek i grup w pożądanym kierunku. Ekonomiści najczęściej zwracają uwagę na następujące zależności ${ }^{50}$ :

1. Dobrze zabezpieczone prawa własności ograniczają niepewność, co pozytywnie oddziałuje na dynamikę inwestycji w różnych formach. Niezabezpieczone prawa własności generują ryzyko wykluczenia, w efekcie czego właściciel nie będzie mógł czerpać korzyści z własności. Skutkiem niewystarczającej ochrony praw własności jest niestabilność otoczenia, w którym działają firmy. Może być to uznane za jedną z przyczyn słabej ekspansji przedsiębiorstw na różne rynki, wewnętrzne i zagraniczne.

2. Prawa własności mają szczególne znaczenie w przypadku inwestycji w nowe techniki i technologie oraz kapitał ludzki. Trudniejsze jest tu zabezpieczenie przed nieuprawnionym użytkowaniem zasobu czy zabezpieczeniem się przed negatywnymi efektami zewnętrznymi. Dobrze chronione prawa własności (np. intelektualnej) pozwalają myśleć inwestorom o przyszłych profitach, planować i organizować swoją działalność w dłuższym okresie oraz wydatkować znaczne sumy na takie inwestycje.

3. Im lepiej zabezpieczone są prawa własności, tym mniejsze koszty transakcyjne. Umożliwia to rozszerzenie przestrzeni transakcyjnej i zwiększenie liczby potencjalnych kontrahentów, bo ich działania

${ }^{50}$ S. Opper, New Institutional Economics and Its Application on Transition and Developing Economies, [w:] New Institutional Economics. A Guidebook, E. Brousseau, J.-M. Glachant (red.), Cambridge University Press 2008, s. 392; P.J. Boettke, P.D. Aligica, B. Hooks, The Millennium Challenge Account: Property Rights and Entrepreneurship as the Engine of Development, Report of Criteria and Methodology for Determining the Eligibility of Candidate Countries for Millennium Challenge Account Assistance in FY, MERCATUS Center George Mason University 2004, s. 11; T. Besley, M. Ghatak, Property Rights and Economic Development, [w:] Handbook of Development Economics, t. 5, D. Rodrik, M. Rosenzweig (red.), Elsevier, North-Holland 2010, s. 4531-5432. 
łatwiej jest przewidzieć. Mogą dzięki temu sprawniej działać rynki dóbr, a także rynki czynników produkcji i szczególnie finansowy.

4. W warunkach słabych praw własności ich rolę mogą przejmować reguły wypracowywane i stosowane przez jednostki (np. korupcja). Prowadzi to do błędnej alokacji zasobów (z punktu widzenia całego społeczeństwa i prawowitych właścicieli), marnotrawstwa, podnosi koszty i zmniejsza siłę bodźców wpływających na intensywność działań podmiotów. Obserwowane mogą być wówczas bezprawne zajęcia majątku i dochodów z niego.

5. Bezpieczne prawa własności są także podstawą utrzymania jakości środowiska i zrównoważonego wykorzystania zasobów naturalnych. Słabe prawa własności, bardziej niż jakiekolwiek inne podstawowe przyczyny, są odpowiedzialne za „tragedię dobra wspólnego”, której przykładem może być degradacja środowiska na całym świecie.

Kanały oddziaływania praw własności na dynamikę gospodarczą są wzajemnie uwarunkowane. Mogą się wzmacniać bądź też oddziaływać negatywnie na siebie. Niezależnie jednak od tego, czy analizujemy kraj o silnych prawach własności, czy też o słabych nie można podważyć tezy o dużym ich znaczeniu w aktywności gospodarczej. Oczywista jest konstatacja, że kraje, które odnotowują wysoki poziom rozwoju gospodarczego są zarazem oceniane jako te, które mają najsilniejsze prawa własności. Powstaje kwestia, jak rozwiązania takie implementować w krajach, gdzie system praw własności jest słaby, jakie konstrukcje prawne zastosować, by stworzone rozwiązania były skuteczne. Normy prawne, które zostały przeniesione z innej gospodarki, mogą nie współgrać z pozostałymi elementami systemu instytucjonalnego, szczególnie z instytucjami nieformalnymi. Konflikty te wymagają wprowadzania kolejnych rozwiązań administracyjnych i regulacji ze strony państwa. Natomiast ewolucyjne powstawanie praw własności z matrycy instytucjonalnej (najgłębiej zakorzenione instytucje nieformalne), mimo że zgodne z innymi instytucjami, może trwać zbyt długo, jak na potrzeby aktualnego rozwoju tych państw. Kwestie te są jednymi z najważniejszych do rozstrzygnięcia w krajach 
rozwijających się. Bez praw własności mechanizm tworzenia kapitału nie mógłby być uruchomiony oraz wpływać na kreowanie potencjału ekonomicznego gospodarki.

\section{Podsumowanie}

Badanie znaczenia praw własności w gospodarce wskazuje na fundamentalną rolę, jaką odgrywają na każdym etapie rozwoju. Z punktu widzenia właściciela tylko formalny tytuł do zasobu umożliwia pełny dostęp do posiadania, użytkowania i dysponowania nim, czyli pełna własność umożliwia racjonalne i efektywne alokowanie zasobów. Staje się fundamentem przedsiębiorczości. Budowanie silnego systemu praw własności posadowionego na instytucjach nieformalnych oraz współgrającego z pozostałymi elementami porządku instytucjonalnego staje się warunkiem osiągnięcia przez dany kraj sukcesu gospodarczego. Czy analizuje się aktywność gospodarczą na poziomie firm, czy porównuje gospodarki w skali makroekonomicznej, w każdym przekroju prawa własności okazują się niezbędne do budowania potencjału ekonomicznego i dynamicznego rozwoju. Bez adekwatnych do stanu gospodarki systemów praw własności mechanizm gospodarczy nie może być samoczynny i samonapędzający się. Pozostaje jednak do rozstrzygnięcia kwestia, jakie rozwiązania prawne są adekwatne do istniejącego układu pozostałych instytucji oraz jak przeprowadzić proces zmian, aby efekty były przynajmniej zadowalające. Odpowiedzi na te pytania stanowią jedne $\mathrm{z}$ fundamentalnych kwestii dotyczących transformacji każdej gospodarki. 